\title{
Annex: the Abidjan Principles Process and the ten Overarching Principles
}

The Abidjan Principles consist of 97 Guiding Principles across six sections. These 97 principles are grouped within ten Overarching Principles within six Sections, which provide an overview and summary of the text. The six Sections and ten Overarching Principles are presented below. The Abidjan Principles are available in full in the adoption languages of English and French at: www.abidjanprinciples.org/en/principles/.

\section{ADOPTION}

The Abidjan Principles were adopted on 13 February 2019 in Abidjan, Côte d'Ivoire by a panel of 20 experts from 14 countries worldwide. This adoption conference also included 68 observers from over 40 countries. The Principles were signed by each expert at a ceremony presided by the Minister of Education in Côte D'Ivoire. The United Nations Special Rapporteur on the Right to Education, Dr Kombou Boly Barry, attended the conference as an expert and participated in the signing ceremony.

\section{THE ABIDJAN PRINCIPLES: SECTIONS AND OVERARCHING PRINCIPLES}

\section{Section I. General Provisions}

(Note: This introductory section contains no Overarching Principles.)

\section{Section II. Obligation to Respect, Protect and Fulfil the Right to Education to the Maximum of Available Resources}

\section{Overarching Principle 1}

States must respect, protect and fulfil the right to education of everyone within their jurisdiction in accordance with the rights to equality and non-discrimination. 


\section{Overarching Principle 2}

States must provide free, public education of the highest attainable quality to everyone within their jurisdiction as effectively and expeditiously as possible, to the maximum of their available resources.

\section{Section III. Obligation to Respect, Protect and Fulfil the Right to Education in the Context of Private Involvement}

\section{Overarching Principle 3}

States must respect the liberty of parents or legal guardians to choose for their children an educational institution other than a public educational institution, and the liberty of individuals and bodies to establish and direct private educational institutions, subject always to the requirement that such private educational institutions conform to standards established by the State in accordance with its obligations under international human rights law.

\section{Overarching Principle 4}

States must take all effective measures, including particularly the adoption and enforcement of effective regulatory measures, to ensure the realisation of the right to education where private actors are involved in the provision of education.

\section{Section IV. Financial Provisions}

\section{Overarching Principle 5}

States must prioritise the funding and provision of free, quality, public education, and may only fund eligible private instructional educational institutions, whether directly or indirectly, including through tax deductions, of land concessions, international assistance and cooperation, or other forms of indirect support, if they comply with applicable human rights law and standards and strictly observe all substantive, procedural, and operational requirements.

\section{Overarching Principle 6}

International assistance and cooperation, where provided, must reinforce the building of free, quality, public education systems, and refrain from supporting, directly or indirectly, private educational institutions in a manner that is inconsistent with human rights. 


\section{Section V. Accountability and Monitoring}

\section{Overarching Principle 7}

States must put in place adequate mechanisms to ensure they are accountable for their obligations to respect, protect, and fulfil the right to education, including their obligations in the context of the involvement of private actors in education.

\section{Overarching Principle 8}

States must regularly monitor compliance of public and private institutions with the right to education and ensure all public policies and practices related to this right comply with human rights principles.

\section{Overarching Principle 9}

States must ensure access to an effective remedy for violations of the right to education and for any human rights abuses by a private actor involved in education.

\section{Section VI. Implementation and Monitoring of the Guiding Principles}

\section{Overarching Principle 10}

States should guarantee the effective implementation of these Guiding Principles by all appropriate means, including where necessary by adopting and enforcing the required legal and budgetary reforms.

\section{THE DRAFTING COMMITTEE}

A Drafting Committee of nine eminent experts led the drafting process and incorporated the comments from the consultations, with inputs from other experts. Over 50 other recognised experts, a majority of them from the Global South, advised on the text and signed it. These experts act in their individual capacity as members of the drafting group facilitating the elaboration of the Abidjan Principles. The institutions listed with the names of the authors are for the purpose of identification rather than endorsement of the commentary given by these institutions. 


\section{Drafting Committee Members}

- Professor Ann Skelton [chair of the Committee] (South Africa; UNESCO Chair for Education Law in Africa; Professor, University of Pretoria; Member, UN Committee on the Rights of the Child)

- Professor Aoife Nolan (Ireland; Professor of International Human Rights Law, University of Nottingham; Member, Council of Europe European Committee of Social Rights)

- Dr Jacqueline Mowbray (Australia; Associate Professor, University of Sydney Law School; external legal adviser, Australian Parliament's Joint Committee on Human Rights)

- Jayna Kothari (India; independent; Co-founder and Executive Director, Centre for Law and Policy Research; Counsel, Karnataka High Court \& Supreme Court of India)

- Dr Magdalena Sepúlveda (Chile; independent; former UN Special Rapporteur on Extreme Poverty; member of the Independent Commission for the Reform of International Corporate Taxation)

- Dr Maria Smirnova (Russia; independent; Honorary Research Fellow, Manchester International Law Centre, University of Manchester)

- Roman Zinigrad (Israel; J.S.D. candidate, University of Yale; Visiting Fellow, Sciences Po Law School)

- Professor Sandra Fredman (South Africa; Professor of the Laws of the British Commonwealth and the USA, University of Oxford; Director, Oxford Human Rights Hub; Honorary Queen's Counsel)

- Sandra Epal Ratjen (France; independent; International Advocacy Director, Franciscans International) 